\title{
DIFFERENCE OF KNOWLEDGE TOWARD HIV/AIDS IN ADOLESCENTS IN SLEMAN, YOGYAKARTA
}

\section{Mario Febrianus Helan Sani, Nanda Agustian Simatupang}

\author{
Masters Program in Public Health, Universitas Sebelas Maret
}

\begin{abstract}
Background: In many countries throughout the world, sexually transmitted disease such as HIV/ AIDS also occurred in adolescents. A study by National Behavioral Surveillance Survey stated that the level of awareness and knowledge among young people about HIV/ AIDS was low. This study was aimed to explore the difference of knowledge toward HIV/AIDS in adolescents in Sleman, Yogyakarta.

Subjects and Method: A descriptive study was carried out at Public Senior High School 1 and Muhammadiyah Senior High School 1, Sleman, Yogyakarta, in April 2019. A sample of 65 students was selected randomly. The study variable was knowledge toward HIV/AIDS. The data were collected by questionnaire and analyzed by Mann whitney test.

Results: Mean of knowledge toward HIV/AIDS in students in Public Senior High School 1 (Mean=63.69; $\mathrm{SD}=24.9)$ was higher than Muhammadiyah 1 Senior High School Sleman $(\mathrm{Mean}=45.84 ; \mathrm{SD}=21.7)$ and it was statistically significant $(\mathrm{p}<0.001)$.

Conclusion: Adolescents knowledge toward HIV/AIDS in Public Senior High School 1 is higher than Muhammadiyah 1 Senior High School, Sleman, Yogyakarta.
\end{abstract}

Keywords: HIV/AIDS, knowledge, adolescents

\section{Correspondence:}

Mario Febrianus Helan Sani. Masters Program in Public Health, Universitas Sebelas Maret. Jl. Ir. Sutami 36A, Surakarta 57126, Central Java. Email: rhyansani@gmail.com. Mobile: +6281326608972. 